virus is strikingly related to that of the other two. Finally, homosexual men have a high prevalence of HIV and hepatitis B virus infections with a low prevalence of antibodies against hepatitis $C$ virus, the presence of which is not related to the presence of either HIV or hepatitis B virus.

1 Choo QL, Kuo G, Weiner AJ, Overby LR, Bradley DW, Houghton M. Isolation of a cDNA clone derived from a blood-borne non-A, non-B viral Isolation of a cDNA clone derived from a

$2 \mathrm{Kuo} \mathrm{G}$, Choo QL, Alter $\mathrm{HJ}$, et al. An assay for circulating antibodies to a major etiologic virus of human non-A, non-B hepatitis. Science 1989;244:362-4.

4 Roggendorf M, Deinhardt F, Rasshofer R, et al. Antibodies to hepatitis C virus. Lancet 1989;ii:324-5.

5 Zuckerman AJ. The elusive hepatitis C virus. BMF 1989;299:871-3.

6 Alter HJ, Purcell RH, Shih JW, et al. Detection of antibody to hepatitis C virus in prospectively followed transfusion recipients with acute and chronic nonA, non-B hepatitis. $N$ Engl f Med 1989;321:1494-500.

7 Bruix J, Calvet X, Costa J, et al. Prevalence of antibodies to hepatitis $\mathrm{C}$ virus in Spanish patients with hepatocellular carcinoma and hepatic cirrhosis. Lance 1989;ii:1004-6.
3 Esteban JI, Esteban R, Viladomiu L, et al. Hepatitis C virus antibodies among risk groups in Spain. Lancet 1989;ii:294-7.

8 Colombo M, Choo QL, Del Ninno E, et al. Prevalence of antibodies to hepatitis $\mathrm{C}$ virus in Italian patients with hepatocellular carcinoma. L ancet 1989;ii:1006-8.

9 Maisonneuve P, Laurian Y, Noel L, Verroust F, Guerols C. Antibodies to $\mathrm{HCV}$ in sexual partners of patients with hemophilia. First international HCV in sexual partners of patients with hemophila.

10 Alter MJ, Coleman PJ, Alexander WJ, et al. Importance of heterosexual activity in the transmission of hepatitis $B$ and non- $A$, non-B hepatitis. activity in the transmis
JAMA 1989:262:1201-5.

11 Centers for Disease Control. Revision of the CDC surveillance case definition for acquired immunodeficiency syndrome. MMWR 1987;36:1-15S

12 Tor J, Muga R, Melus R, et al. HIV infection prevalence in intravenous drug abusers in Barcelona 1984-1987. European conference on clinical aspects of HIV infection. [Abstract.] Brussels, 1987.

13 Tor J, Ginesta C, Muga R, Clotet B, Rey-Joly C, Foz M. Information on HIV-1 transmission and sexual behavior in couples of intravenous drug abusers. Fifth international conference on AIDS. [Abstract.] Montreal: World Health Organisation, 1989.

14 Cadeo GP, El-Hamad J, Rodella A, et al. Preliminary report on hepatitis C antibodies prevalence among high risk groups and blood donors in the area of Brescia. First international symposium on hepatitis $C$ virus. [Abstract.] Rome, 1989.

15 Mortimer PP, Cohen BJ, Litton PA, et al. Hepatitis C virus antibody. Lancet 1989;ii:798.

(Accepted 7 September 1990$)$

\section{Women in prison and use of illicit drugs before arrest}

\author{
Anthony Maden, Mark Swinton, John Gunn
}

Department of Forensic Psychiatry, Institute of Psychiatry, London SE5 8AF

Anthony Maden,

MRCPSYCH, research worker

Mark Swinton, MRCPSYCH, research worker

John Gunn, FRCPSYCH, professor

Correspondence to: Dr Maden.

BrMed f 1990;301:1133
From 1979 to 1988 the number of sentenced women in prison rose by $32 \%$ yet the number of women sentenced for drug offences increased by over $400 \%$. $^{.}$We present the results of a retrospective survey of drug use before arrest among female prisoners.

\section{Subjects, methods, and results}

We interviewed a random sample of 272 women serving a prison sentence (a quarter of the prison population) about drug use in the six months before arrest. Data collected included the type of drug and the frequency and route of use. Dependence on a drug was defined as daily use plus withdrawal symptoms on abstinence and an acceptance by the woman that she was dependent. Drug users were asked about their previous contact with treatment agencies and their current attitude to treatment without drugs.

Cannabis was the illicit drug that had been used most commonly, with 82 women reporting use at least once a week. It was excluded from consideration of drug dependence as it is of minor clinical importance.

Sixty three women $(23 \% ; 95 \%$ confidence interval $18 \%$ to $28 \%$ ) were identified as drug dependent (table). Most had used opiates, alone or in combination with other drugs, and most had injected during the six months before their arrest. Of these 63 women, 24 had been sentenced for drug offences and 32 for theft. Thirty seven stated that they would accept treatment if it was offered, including 17 who seemed to have a strong desire for treatment. The 26 women who expressed no desire for treatment usually stated that drugs were no longer a problem; only one or two were resigned to a return to dependency. Two drug users were positive for HIV (the number tested was unknown).

\section{Comment}

Nearly a quarter of sentenced female prisoners were dependent on drugs at the time of their offence. Despite recent diversification in facilities for treating drug users ${ }^{2}$ one third of the women who were dependent on drugs reported having had no contact with services before entering prison. Our findings support the claim by the advisory council on the misuse
Type of drug used before arrest by female prisoners who were drug dependent, and number reporting previous treatment for dependency

\begin{tabular}{lccc}
\hline & $\begin{array}{c}\text { Injected during six } \\
\text { months before } \\
\text { arrest }\end{array}$ & $\begin{array}{c}\text { Reported previous } \\
\text { treatment for } \\
\text { drug dependency }\end{array}$ & Total \\
Type of drug & 22 & 22 & 34 \\
\hline Opiates alone & 14 & 14 & 16 \\
Opiates and other drugs & 6 & 4 & 13 \\
Non-opiate drugs & 42 & 40 & 63 \\
\hline Total & & &
\end{tabular}

of drugs that prison or the courts can offer an important point of contact for drug users not seen elsewhere. ${ }^{3}$ Women's prisons have no equivalent of the therapeutic regimens available to men at Grendon and Wormwood Scrubs annexe. Many of the women expressed a desire for treatment. Motivation is difficult to assess in prison; the only real test is to make treatment available.

Past criticism of provision for drug users drew attention to the absence of effective liaison at the time of release. ${ }^{1} \mathrm{~A}$ recent policy statement by the Home Office on developing services in prisons emphasises the need for coordination between prisons and outside agencies and encourages prison doctors to take a more active role in this process. ${ }^{5}$

1 Home Office. Prison statistics England and Wales 1988. London: HMSO, 1989. 2 Strang J "The British system": past, present and future. International Review of Psychiatry 1989;1:109-20.

3 Department of Health and Social Security. Report by the advisory council on the misuse of drugs. AIDS and drug misuse part I. London: HMSO, 1988.

4 House of Commons Social Services Committee. Third report: the prison medical service. London: HMSO, 1986.

5 Home Office. Policy statement on throughcare of drug misusers in the prison system. London: Home Office Prison Department, 1988.

(Accepted 13 fuly 1990)

\section{Notice of inadvertent duplicate publication}

The $B M f$ regrets that the paper entitled "Quality of life of elderly people after surgery for benign oesophageal stricture" by Dr B N M Jayawardhana and others (16 December 1989, pp 1503-4) was substantially similar to a paper published in Age and Ageing entitled "Benign oesophageal stricture: the place of surgery in the management of elderly patients" (January 1990, pp 31-5). Although these papers included some of the same group of patients and addressed the same question, neither editor was informed of the existence of the other paper, in contravention to our instructions to authors and to internationally agreed guidelines. 